\title{
Judicial Review in an Integrated Administration: the Case of 'Composite Procedures'
}

\author{
Mariolina Eliantonio* \\ Faculty of Law, Maastricht University
}

\begin{abstract}
In the past years, increasingly more and more forms of cooperation have been set up across the different national and European administrative levels with the aim of putting European policies into effect. While the administrative level is becoming more 'integrated', the judicial system remains based on a strict separation between the EU and the national levels of jurisdiction.

The aim of this article is to show how the operation of the system of integrated administration' may pose problems of judicial accountability. The gaps in judicial protection will be examined using the example of the 'composite procedures', i.e. decision-making processes with input from administrative actors from different jurisdictions, where the final decision, issued by a Member State or an EU authority, is based on procedures involving more or less formalized input of the various participating authorities.

After categorising the various composite procedures, the problems connected with access to court when challenging measures adopted in the course of the composite procedures will be analysed, together with an exemplification of these problems by use of a specific case study. Throughout the discussion, the relevance of the recently published ReNEUAL Model Rules will be specifically address and evaluated. Finally, solutions will be brought forward as to how the identified gaps could be effectively filled.
\end{abstract}

* DOI $10.7590 / 187479814 X_{14186465138022}$ 


\section{Introduction}

'[M]aintaining legality and effective supervision of composite procedures is a challenging task in the face of this ever-evolving network structure'1

The European Union (EU) is traditionally considered as a 'multi-level' legal system, in which EU and domestic legal systems operate in an interlocked fashion. ${ }^{2}$ The numerous and complex links between EU and national institutions have given rise to an increasing need for cooperation at the legislative, executive and judicial levels. With particular regard to the executive level, scholarly debate has observed the emergence of an 'integrated administration' or 'administrative Union' ('Verwaltungsverbund'), indicating the progressive interlinking of national and European administrations with the aim of putting European policies into effect.

Traditionally, the schemes for the administrative implementation of European law have been categorised into direct and indirect administration, in accordance with the general framework of executive federalism. ${ }^{3}$ Under this model, the Member States through their national authorities would mainly implement European law, while in exceptional cases it would be the European institutions in charge of giving effect to European policies. Depicting the current models of EU law implementation in this way, would, however, hardly do justice to its complexity. In particular, it would ignore the fact that increasingly more and more forms of cooperation have been set up across the different administrative levels. ${ }^{4}$ This system has been described as one of 'integrated administra-

1 Herwig C.H. Hofmann, 'Decisionmaking in EU Administrative Law - The Problem of Composite Procedures' (2009) Administrative Law Review, 221.

2 L. Hooghe \& G. Marks, Multi-level governance and European integration (Rowman and Littlefield 2001); B. Kohler Koch (Ed.), Linking EU and national governance, Oxford University Press 2003; B. Kohler-Koch \& R. Eising (Eds), The transformation of governance in the European Union, Routledge 1999.

3 Jurgen Schwarze, European Administrative Law, Sweet and Maxwell 1992, 25-47; Stefan Kadelbach, 'European Administrative Law and the Law of a Europeanised Administration', in: Christian Joerges \& Renaud Dehousse (Eds), Good Governance in Europe's Integrated Market Oxford University Press 2002, 167; Jacques Ziller, 'Introduction - Les concepts d'administration directe, d'administration indirecte et de coadministration et les fondements du droit administratif europeen', in: Jean-Bernard Auby et Jacqueline Dutheil de la Rochere (Eds) Traité de Droit Administratif Europeen, Bruylant 2014, $327 \mathrm{ff}$.

4 Hofmann claims that 'this model has always been a simplification of reality'. Herwig C.H. Hofmann, 'Composite decision making procedures in EU administrative law', in: Herwig C.H. Hofmann \& Alexander H. Türk (Eds), Legal Challenges in EU Administrative Law, Elgar 2009, 137. The inadequacy of the dichotomy between direct and indirect administration had already been put in question in 2006 in Herwig C.H. Hofmann \& Alexander H. Türk, 'An introduction to EU administrative governance', in: Herwig C.H. Hofmann \& Alexander H. Türk (Eds), EU administrative governance, Elgar 2006, 3 . 
tion', in order to convey the idea that supranational and national institutions cooperate and are linked together in the process of implementation of European law. ${ }^{5}$

The idea of 'integrated administration' implies not only a departure from the traditional notions of direct and indirect administration, but also a need to re-think the dualistic approach to the judicial review of administrative action, which is based on a strict separation between the EU and the national levels of jurisdiction. This strict separation implies that measures of the EU legal system fall under the jurisdiction of the CJEU solely, while measures of national authorities would fall under the authority of the courts that have jurisdiction according to the domestic rules of the legal system from which the challenged measure originates. Seen from the traditional point of view of executive federalism, this system would imply that, in cases of indirect execution, private parties should be able to challenge national implementation measures before national courts (and also possibly challenge the validity of the enabling European measure under the preliminary ruling procedure contained in Article 267 TFEU). Whereas, instead, the execution of EU law would be entrusted to the Commission, private parties would be given access to the European courts following the procedure of the action for annulment contained in Article $26_{3}$ TFEU. ${ }^{6}$

However, since most of the activities in the system of 'integrated administration' do not follow a clear hierarchical nature, the responsibility for a certain action may be shared between different actors and at varying levels. As has been argued 'some of the central challenges for national and European administrative law now involve controlling heterarchical structures"7 i.e. situations in which administrations take their final decisions on the basis of input from different administrative authorities operating in various national legal systems as well as the EU legal system. ${ }^{8}$ This system may pose problems for access to court

5 Herwig C.H. Hofmann, 'Conclusions: Europe’s integrated administration', in: Herwig C.H. Hofmann \& Alexander H. Türk (Eds), EU Administrative Governance, 583; Eberhard SchmidtAßmann, 'Introduction', in: Oswald Jansen \& Bettina Schöndorf-Haubold (Eds), The European Composite Administration, Intersentia 2011, 6-8.

6 For a comprehensive introduction to both of these procedures and the system of judicial protection in the EU legal system, see Paul Craig \& Grainne de Burca, EU Law: Text, Cases, and Materials, Fifth Edition 2011, Oxford University Press.

7 Herwig C.H. Hofmann \& Alexander H. Türk, 'Conclusions: Europe’s integrated administration', 580.

8 See also on this point, concerning agencies and comitology committees, Deirdre Curtin, 'Holding (Quasi-) Autonomous EU Administrative Actors to Public Account, European Law Journal' (2007) European Law Review, 523-541. And generally see, Carol Harlow \& Richard Rawlings, 'Promoting Accountability in Multilevel Governance: A Network Approach' (2007) European Law Journal, 542-562. 
and, consequently, endanger the principle of effective judicial protection, which is enshrined in Article 47 of the Charter of Fundamental Rights and has long been considered by the CJEU as a general principle on EU law, binding on the EU and the Member States legal systems alike. ${ }^{9}$

The aim of this article is to show how the operation of the system of 'integrated administration' may pose problems of judicial accountability. The gaps in judicial protection will be examined using the example of the 'composite procedures', i.e. decision-making processes with input from administrative actors from different jurisdictions, where the final decision, issued by a Member State or an EU authority, is based on procedures involving the more or less formalised input of the various participating authorities.

After categorising the various composite procedures, the problems connected with access to court when challenging measures adopted in the course of the composite procedures will be analysed, together with an exemplification of these problems by use of a specific case study. Throughout the discussion, the relevance of the recently published ReNEUAL Model Rules will be specifically address and evaluated. ${ }^{10}$ Finally, solutions will be brought forward as to how the identified gaps could be effectively filled.

\section{Composite Procedures: Definition and Categorisation}

\subsection{What are Composite Procedures?}

As mentioned in the introduction, the focus of this paper will be on one specific structure operating according to the system of 'integrated administration', namely that of the composite procedures. ${ }^{11}$ These have been defined as procedures entailing the input of administrative actors from different jurisdictions, and in which the final decision, issued by a Member State or a

9 See e.g. Case C-279/o9 DEB [2010] ECR I-13849; Case C-12/o8 Mono Car Styling [2009] ECR I-6653, para. 49 ('whilst it is, in principle, for national law to determine an individual's standing and legal interest in bringing proceedings, [EU] law nevertheless requires, in addition to observance of the principles of equivalence and effectiveness, that the national legislation does not undermine the right to effective judicial protection'). Further on this principle and its implications, see Sacha Prechal \& Rob Widdershoven 'Redefining the Relationship between "Rewe-effectiveness" and Effective Judicial Protection' (2011-2) REALaw, 31-50.

10 See for an overview of the project, the website of the organization at http://reneual.eu.

11 These procedures have also referred to as 'mixed administrative proceedings'. Giacinto Della Cananea, 'The European Union's Mixed Administrative Proceedings' (2004) Law and Contemporary Problems, 197. 
EU authority, is based on procedures involving the more or less formalized input of the various participating authorities..$^{2}$ The drafters of the ReNEUAL Model Rules have similarly defined composite procedures as administrative procedures 'where EU authorities and the authorities of a Member State or of different Member States have distinct functions which are interdependent'. ${ }^{13}$ While there is not one official definition of composite procedures, the phenomenon can be captured indeed in the 'interdependence' of national and EU authorities in the process of carrying out their administrative functions for the purposes of implementing EU law.

Therefore, the composite procedures should be distinguished from the systems of direct or indirect administration. Since in the latter two situations the administrative action is carried out either solely at the national level (while the EU level limits itself to the abstract and general rule-making), or solely at the EU level without involvement of national administrative authorities. In the composite procedures, instead, administrative decision-making is carried out at both national and European level.

This definition also serves to distinguish composite procedures from other types of similar procedures, such as linked and complex proceedings. ${ }^{14}$

While useful for the purposes of distinguishing the system of composite procedures from other related mechanisms, the definition provided above, because of its general nature, lacks comprehensive explanatory value. In order to understand the true operation of the composite procedures, in lack of a legal framework, it is therefore necessary to look into the specific legal and administrative arrangements of the policy fields concerned and attempt at categorising the different procedures.

\subsection{Possible Categorisations of the Composite Procedures}

There have been attempts to categorize these arrangements; however, as has been suggested, this exercise is 'fraught with considerable complexity'. ${ }^{15}$ This complexity is mostly due to the lack of a harmonized approach

12 Herwig C.H. Hofmann, Gerard C. Rowe \& Alexander H. Türk, Administrative Law and Policy of the European Union (Oxford University Presss 2011), 406.

13 Article I-4(4) of the ReNEUAL Model Rules. See further for the explanation of the term, Part C of Book I of the ReNEUAL Model Rules, para. 21.

14 Giacinto Della Cananea, The European Union's Mixed Administrative Proceedings, 210-211.

15 Herwig C.H. Hofmann, Gerard C. Rowe \& Alexander H. Türk, Administrative Law and Policy of the European Union, 15 . 
throughout the policy fields. ${ }^{16}$ As the drafters of the ReNEUAL Model Rules have observed, 'the current rules and procedures for administrative procedures are fragmented and mostly policy-specific; there are gaps and it is not always possible to have a coherent interpretation of the rules that apply in different sectors, even though they are intended to be similar'. ${ }^{17}$ For this reason, as of today, it can certainly be argued, and as it has been by Türk and Hofmann, that ' $[t]$ he terminology used in the nascent field of EU administrative law is not yet established'. ${ }^{8}$

In very general terms, and from a functional point of view, it has been argued that composite procedures could be categorised from either the point of view of the substance of the procedure, or from that of the level of authority taking the final administrative decision. ${ }^{19}$ Additional to these two functional criteria, a third criterion concerning the type of authorities involved in the decision-making has been added by the doctrine. For the purposes of a comprehensive analysis, it is submitted that a fourth categorisation based on the steps of the procedure would be useful.

\subsubsection{The Authority Taking the Final Decision}

A basic categorisation of the composite procedures departs from the determining criterion of which authority takes the final decision in the administrative decision-making proceedings. ${ }^{20}$ Composite procedures necessarily entail the participation of multiple authorities, belonging to the national or the European system of administration. At the end of the decisionmaking process, there are two possible options: either the final measure is taken by a national authority (and may have effect beyond its national territory) or by a European authority. From this perspective, all other activities, whether stemming from a national or a European authority, are of preparatory nature in the decision-making process.

\section{Ibid., 15 .}

Introduction to the ReNEUAL Model Rules; Book I - General Provisions; para. 14.

\section{Herwig C.H. Hofmann \& Alexander H. Türk, 'Legal Challenges in EU administrative law by} the move to an integrated administration', in: Herwig C.H. Hofmann \& Alexander H. Türk (Eds), Legal Challenges in EU Administrative Law (Elgar 2009), 358.

19 Herwig C.H. Hofmann, Gerard C. Rowe \& Alexander H. Türk, Administrative Law and Policy of the European Union, 16.

20 Giacinto Della Cananea, 'The European Union's Mixed Administrative Proceedings', Law and Contemporary Problems (2004), 197-218; Edoardo Chiti, 'The Administrative Implementation of European Union Law: a Taxonomy and its Implications', 9-33. 


\subsubsection{The Substance of the Procedure}

The second categorisation criterion focuses on the activities that are preparatory to the decision-making process. These can be of various types, but can roughly be distinguished into two main forms: information and decision. The scholars who have set up the first type of categorisation, by looking mostly at the type and forms of information sharing, have come to the conclusion that administrative cooperation in information sharing could range from an ad hoc single-case information exchange to structured procedures involving constant streams of information. These streams proceed both vertically between the EU and the Member States - and horizontally - between the Member States themselves (with or without a role assigned to the European institutions). ${ }^{21}$ The exchange can consist of information provided upon request, the provision of a document or even the request of an inspection. ${ }^{22}$ In the ReNEUAL Model Rules, these actions are categorized under the overarching concept of 'mutual assistance' and are governed by Book V of the Model Rules. ${ }^{23}$ If instead the information would be exchanged through a structured information mechanism, under a duty to inform without prior request or through the use of a database, Book VI of the ReNEUAL Model Rules would be applicable. ${ }^{24}$

Apart from the participation of national or European authorities in the decision-making process through the (ad-hoc or continuous) submission of information, another form of cooperation between national and European authorities can consist of a more 'institutionalised' decision. In other words, an administrative authority contributes in the decision-making not by sharing or providing information, but by adopting a measure in the form of an opinion, for example, or a binding measure such as a Commission Regulation.

\subsubsection{The Types of Authority Involved}

A third categorisation is based on the authorities relevant for the procedures, as is the case for the categorisation discussed above. This last one, however, looks and categorises the procedures from the perspective of the

21 Eberhard Schmidt-Aßmann, 'Verwaltungskooperation under Verwaltungskooperationsrecht in der Europäischen Gemeinschaft' (1996) Europarecht, 270; Eberhard Schmidt-Aßmann, 'Introduction', 6 and ff. See also Jens-Peter Schneider, 'Basic Structures of Information Management in the European Administrative Union’ European Public Law (2014) 89-106.

22 Florian Wettner, 'The General Law of Procedure of EC Mutual Administrative Assistance', in: Oswald Jansen \& Bettina Schöndorf-Haubold (Eds), The European Composite Administration, 307-334.

23 See Part A, Section I of Book V - Mutual Assistance, especially para. 5, and Article V-1(2) of the ReNEUAL Model Rules.

24 See further Part C of Book VI of the ReNEUAL Model Rules. 
type of authorities involved at all stages of the procedure, rather than only at the level of authority taking the final decision. ${ }^{25}$ This type of taxonomy shows that the different forms of cooperation may range from a stable cooperation between the Member States with very limited or no European coordination, to a fully-fledged 'European common system coordinated by the Commission'. ${ }^{26}$

\subsubsection{The Steps of the Procedure}

A fourth categorisation could be carried out on the basis of the steps in the decision-making procedure. The participation of the different authorities may take multiple shapes, depending on the applicable legislation. The simplest model of composite procedure involves only two steps, with a preparatory activity carried out by a national authority and a final measure being taken at the European level, or vice versa, as depicted below.
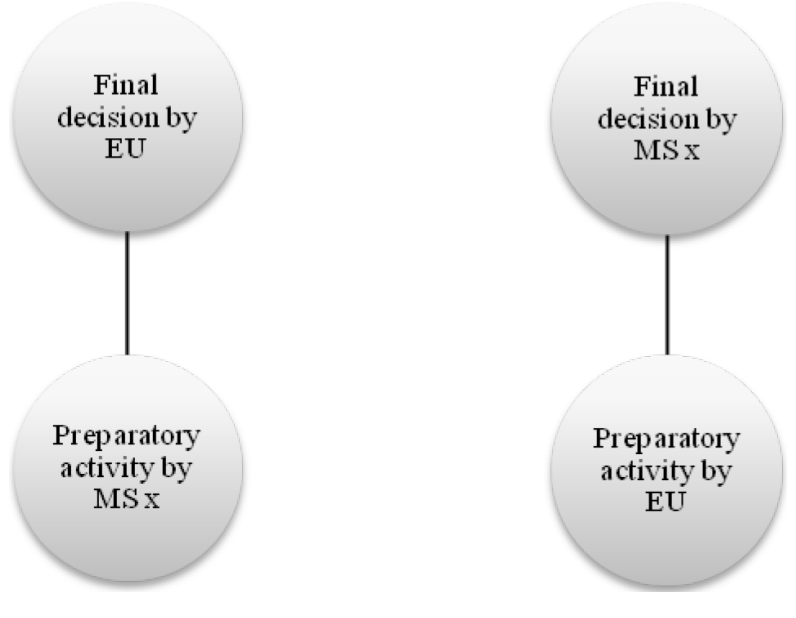

Figure 1: double-step composite procedures

An example of the first type of proceedings depicted in Figure 1 is in the context of the management of certain types of subsidies in the agricultural sector. According to the applicable legislation, ${ }^{27}$ the application for financing

25 Edoardo Chiti, 'The Administrative Implementation of European Union Law: a Taxonomy and its Implications', 14 and ff.

26 Ibid., 25.

27 See e.g. Council Regulation No $1782 / 2003$ of 29 September 2003 establishing common rules for direct support schemes under the common agricultural policy and establishing certain support schemes for farmers [2003] OJ L 270/1. 
(e.g. for the olive oil market) must be made to the national competent authorities, which conduct an initial examination of the application. They form an opinion that is sent to the Commission, which adopts a decision containing a list of fundable projects.

An example of the proceedings with the final decision being taken at the national level can also be found in the area of awarding of funds. Typically, in such situations, there is a basic Regulation adopted by the Council, and then the Commission is empowered to implement these rules, by awarding funds to the Member States. The latter are made responsible for receiving applications, giving money to applicants where the conditions are met and possibly request reimbursement when the Commission so requires. ${ }^{28}$

A second, more complex type of procedure could be characterised as a 'back and forth' flow of activities, which start and end at the national level and involve the participation of the European authorities only at the intermediate level.

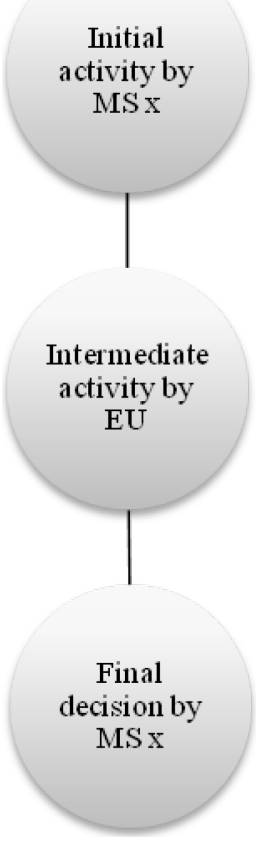

28 See e.g. Council Regulation (EC) No 1260/2001 of 19 June 2001 on the common organisation of the markets in the sugar sector [2001] OJ L 178/1-45. 
Figure 2: 'back and forth' composite procedures

An example of this procedure is the designation of the protected areas in the context of the Habitats Directive. ${ }^{29}$ Firstly, each Member State is obliged to propose a list of ecological sites, which are in their opinion of Community importance. Then that list has to be transmitted to the Commission, who adopts a list of sites selected as sites of Community importance. Finally, Member States are obliged to designate the sites in their territory as 'special areas of conservation'.

More complex, than the procedures discussed above, are a variety of 'hybrid' proceedings that entail the participation of national and European authorities at the same time and at different moments in the decision-making process. For example as in the schematic depictions provided and explained below.

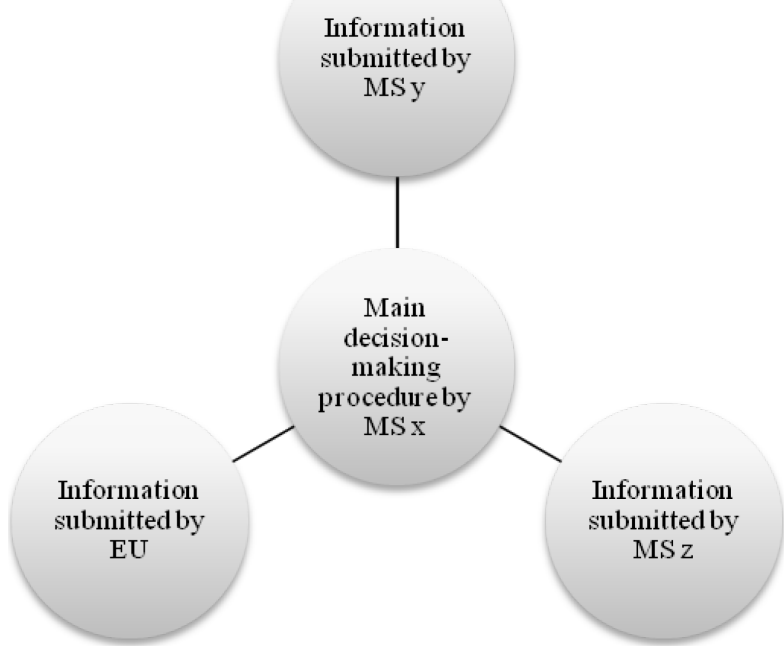

Figure 3: hybrid model 1

In the model depicted in Figure 3, the administrative-decision making procedure is carried out within one Member State and EU institutions or other Member States submit information. This model can be found in Council Directive $2001 / 18$, concerning the deliberate release into the environment of genetic- 
ally modified organisms..$^{30}$ According to this procedure, the marketing application must be submitted to the national competent authorities. The decisionmaking process leading to the authorisation therefore takes place at the national level, but the Commission and the other Member States may intervene in the process by submitting information. ${ }^{31}$

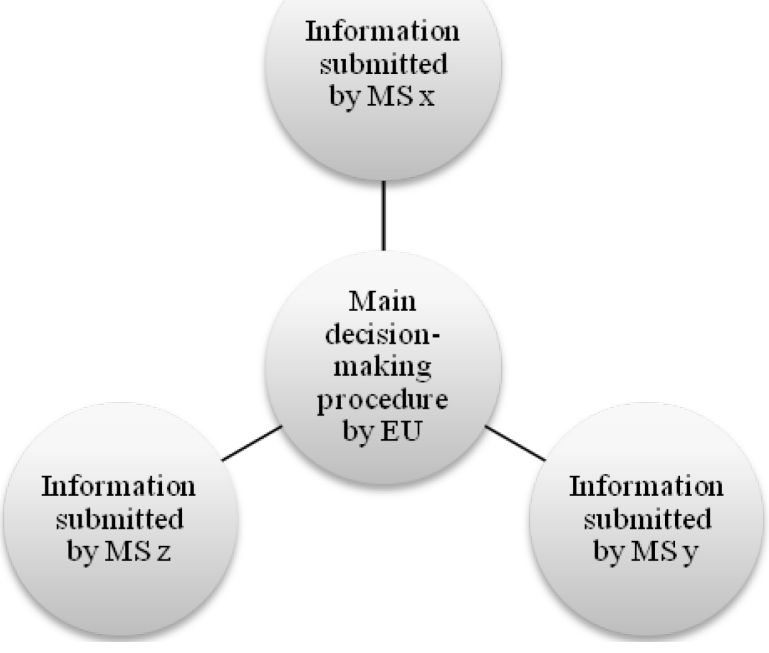

Figure 4: hybrid model 2

Conversely with respect to the first hybrid model, in the procedure illustrated above in Figure 4, the main decision-making procedure is carried out at the EU level and information is submitted by Member States. This model is used, for example, in the 'centralised procedure' provided in Regulation 726/2004 on the marketing authorisation for medicines. Here the Commission takes the final authorization decision, and the Member States have the chance to submit observations in the course of the decision-making process. ${ }^{32}$

30 Directive 2001/18/EC of the European Parliament and of the Council of 12 March 2001 on the deliberate release into the environment of genetically modified organisms [2001] OJ L 106/1.

31 Please note, however, that if reasoned objections to the marketing authorization are submitted (by either the Commission or another Member State), different procedures than the one examined above will apply. For a detailed description of the procedure see, A. Keessen, European Administrative Decisions - How the EU Regulates Products on the Internal Market (Europa Law Publishing 2009), $36 \mathrm{ff}$.

32 Regulation No 726/2004 of the European Parliament and of the Council of 31 March 2004 laying down Community procedures for the authorisation and supervision of medicinal products for human and veterinary use and establishing a European Medicines Agency [2004] OJ L 136/1. Further on this, A. Keessen, European Administrative Decisions - How the EU Regulates Products on the Internal Market, $43 \mathrm{ff}$. 


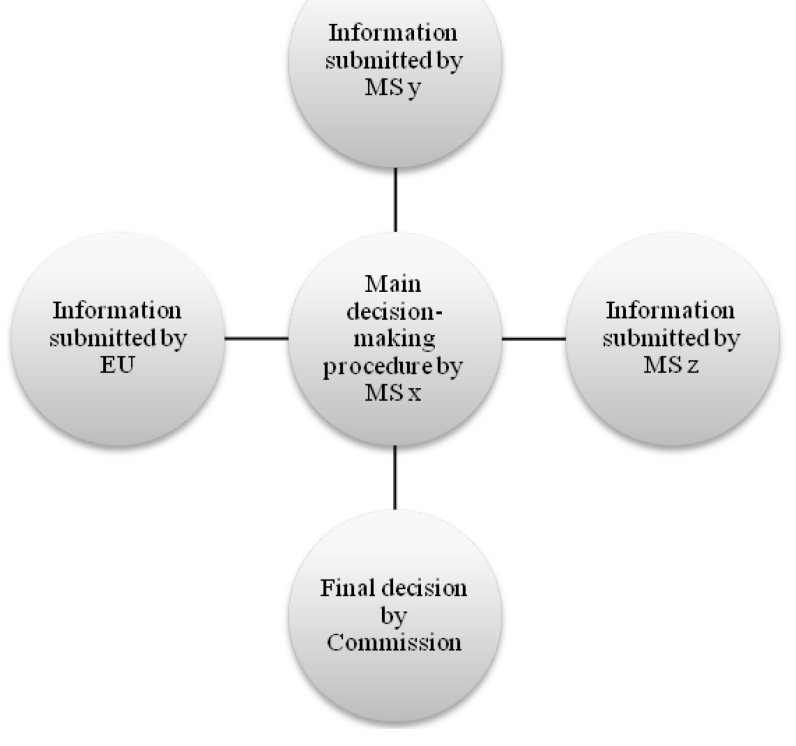

Figure 5: hybrid model 3

Finally, the most complex model is, as provided in Figure 5, the one in which the administrative decision-making procedure commences in one Member State, followed by input from the EU level or another Member State, and then the Commission takes the final decision. An example of this model is contained in the procedure arising out of Regulation 258/97 concerning novel foods and novel food ingredients. ${ }^{33}$ To market a novel food or ingredient, companies must apply to a EU country's national authority, which must draw up a safety assessment report, that is then forwarded to the Commission (who in turn forwards it to the other Member States), and in which the national authority states whether the product requires an 'additional assessment' (to be carried out at the EU level). The Commission and the national authorities, at that point, have the chance to present their objections on the marketing or proposed labeling of the product. Unless the so-called 'simplified procedure' applies (i.e. where no additional assessment was deemed necessary and no objections were submitted), ${ }^{34}$ the Commission then takes the final decision of approval. 
The categorisation ${ }^{35}$ issues sketched above, point to a significant conceptual difficulty that is not only theoretical in nature, but also closely linked to more substantial issues, including namely transparency and participation issues linked to the proceedings, the efficiency and effectiveness of such multi-level decision-making structures and, finally, the accountability of the actors involved in the decision-making proceedings. This last issue will be the subject matter of the remainder of this paper.

\section{The Gaps of Judicial Protection in the System of Integrated Administration}

\subsection{Introduction}

As mentioned in the introduction, while EU administrative decision-making has abandoned the traditional dichotomy between direct and indirect administration, and is more and more often organised in a networked and multi-level system; the supervision and accountability are still linked in a two-level system, with separate national and EU levels.

This means that, on the basis of an orthodox application of the notion of executive federalism and the separation of labour between national and European courts, the judicial level competent in shared administrative procedures corresponds to the administrative level that has adopted the act under challenge. For as far as Member States' participation in the composite procedures are concerned, it will be national courts which will have jurisdiction, while European measures should be challenged before European courts subject to the applicable European procedural rules.

Once the competent level has been identified, the subsequent problem is in understanding in which part of the process the identified judicial instance will have jurisdiction. With regard to this issue, a traditional understanding of the two-level system of judicial supervision of the implementation of EU law would lead to the conclusion that each instance is competent for only the acts emanating from the authorities falling within its jurisdiction. Consequently national courts would not be allowed to review the legality of measures issued by the European authorities or non-domestic national authorities, and similarly

35 Furthermore, Della Cananea notes other ways to categorize the procedures, e.g. those taking place on a yearly basis (e.g. in the agricultural field) and those instead taking place only after the individual files an application (e.g. placing medicines on the market), Giacinto Della

Cananea, 'The European Union's Mixed Administrative Proceedings', 205. 
EU courts would not have jurisdiction to assess the legality of national administrative measures.

Thirdly, once the competent judicial instance has been identified, and the scope of its jurisdiction has been clarified, a subsequent question is on which kind of measures the competent courts can exercise their judicial review powers. The question of the reviewable acts is an important one in the context of the composite procedures. If measures can be challenged only before the courts having jurisdiction over the authority issuing the measure, and if national courts cannot assess the legality of measures linked to those directly challenged not falling within their jurisdiction, then it is inevitable that some challenges need to be directed against measures which are initial or intermediate in the decisionmaking process.

Furthermore, whatever the competent judicial authority, its scope of review and the nature of the act being challenged; it is necessary for applicant to obtain standing to challenge the specific measure at stake.

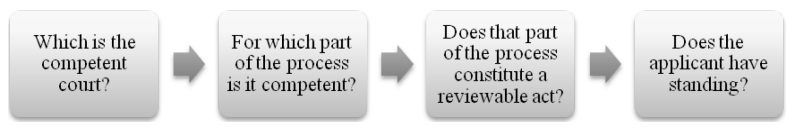

Figure 6: judicial protection questions in composite procedures

The figure above depicts the four subsequent sets of questions to be answered in order for a private party to be able to challenge measures taken within the system of composite procedures. This complex system of allocation of labour amongst the national and European jurisdiction may give rise to a range of problems: firstly, if the challenge is directed towards a preparatory step of the procedure, the measure at stake may not constitute a reviewable act or omission in the (national or European) legal system in which it occurred. Moreover, the applicant may not fulfill the requirement to have standing before the (national or European) competent court. Furthermore, if the challenge is directed towards the final measure of the decision-making process (and assuming that the applicant is challenging a reviewable act and has standing to bring the claim), the action may not be able to cover errors which occurred at other levels than the one which took the final decision, while, at the same time, access to court is barred for all the steps which took place before the final measure was issued.

It is therefore necessary to analyse the problems of standing and the existence of a reviewable act both at the national and EU level, in order to identify the possible gaps of judicial protection in composite procedures. These two issues will be analysed in turn in the next two sections. 


\subsection{The Existence of a Reviewable Act}

\subsubsection{Reviewable Acts at the EU Level}

As far as the EU contribution to a composite procedure is concerned, the action can consist of an act (having a positive or a negative content) or an omission. Each action or inaction can be initial, intermediate or final in the administrative-decision making process. While the administrative action is challengeable in the EU legal system directly under Article $26_{3}$ TFEU, through an action for annulment, or indirectly through a preliminary question of validity, under Article 267 TFEU. Meanwhile the EU inaction can be the subject matter of an action for failure to act under Article 265 TFEU. ${ }^{6}{ }^{6}$ Below the reviewability of the EU action and inaction in the composite procedures will be reviewed.

\subsubsection{Action for Annulment}

Pursuant to Article 263 TFEU, the European court may review the legality of acts 'other than recommendations and opinions'. Under the case law developed before the Lisbon Treaty (and concerning the predecessor of Article $26_{3}$ TFEU, i.e. Article 230 EC), the scope of reviewability of EU measures was extended to 'all measures adopted by the institutions, whatever their nature or form, which are intended to have legal effects' ${ }^{37}$ As far as private parties are concerned, they also need to prove that 'the measure is binding on, and capable of affecting the interests of, the applicant by bringing a distinct change in his legal position'. ${ }^{38}$ While this criterion does not seem to pose problems with respect to final measures of the decision-making process, because a final measure is certainly capable of affecting an individual's legal sphere, the criterion may pose a significant hurdle with regard to initial and intermediate measures. These cases will be analysed in turn by distinguishing between positive and negative measures.

\section{Positive Measures}

EU positive measures that initiate a decision-making process are generally not considered reviewable by the European courts. The authority for this statement is contained in the IBM case in which the CJEU held that a measure is reviewable only if it is 'definitively laying down the position of the Commission

36 Please note that this setup is not altered by the ReNEUAL Model Rules, which explicitly state, in the context of a proposed duty to indicated the available remedies (contained in Article III30), that 'Article III-30 does not introduce any innovation with regard to existing judicial and non-judicial remedies at EU level'. Part C, Chapter 5 of the ReNEUAL Model Rules, para. 118.

37 Case 22/70 Commission v. Council (ERTA) [1971] ECR 263, para. 42.

38 Case 6o/81 IBM v. Commission [1981] ECR 2639, para. 9. 
or the Council in the conclusion of that procedure, and [is] not a provisional measure intended to pave the way for a final decision' ${ }^{39}$

Similarly, and by applying the IBM case law, EU contributions to a composite procedure will generally not constitute reviewable acts because they are considered as provisional, preparatory measures. ${ }^{40}$ This conclusion is equally applicable regardless of whether the final decision is taken at $\mathrm{EU}^{41}$ or national level. ${ }^{42}$ However, if the final decision is taken at the European level, it is possible to challenge the preparatory measure in a claim brought against the final measure. ${ }^{43}$

Initial or intermediate EU measures have, therefore, been considered as reviewable only where they are capable of affecting the applicant's legal sphere independently of the final decision. This was the case in AKZO Nobel, for example, where the Court held that during on-the-spot investigations in competition cases, the physical act of seizing the documents and placing them into the investigation file could constitute a reviewable decision under Article $26_{3}$ TFEU, as it may violate the applicant's right to confidentiality irrespective of the possible violation of competition rules. ${ }^{44}$

\section{Negative Measures}

It is not entirely clear under which circumstances it is possible to challenge the EU institutions' refusal to initiate or contribute to a procedure. First of all, it is clear that silence is not to be equated to an implied refusal. ${ }^{45}$ Also, the European courts have made clear that 'an act of the Commission which amounts to a rejection must be appraised in the light of the nature of the request to which it constituted a reply'. ${ }^{46}$ In other words, a measure of rejection is not reviewable if the act, which the individual requested the EU institutions to adopt, is itself not reviewable. By applying the IBM case law discussed above, a rejection to issue an initial or intermediate measure in a composite procedure would

\footnotetext{
Ibid., para. 10.

Case C-521/04 P(R) Tillack v. Commission [2005] ECR I-3103.

See e.g. case T-123/03 Pfizer v. Commission [2004] ECR II-1631, para. 32, where the challenge concerned a measure of referral of the investigation by the Commission to the European Agency for the Evaluation of Medicinal Products. See e.g. Case T-160/98 Van Parijs and Pacific Fruit Company v. Commission [2002] ECR II-233. Case T-123/o3 Pfizer v.Commission [2004] ECR II-1631, para. 23.

Joined Cases T-125 \& 253/03 Akzo Nobel Chemicals and Akcros Chemicals v. Commission [2007] ECR II-3523.

45 Case C-123/03 P Commission v. Greencore [2004] ECR I-11647, para. 45.

46 Case T-369/03 Arizona Chemical and others v. Commission [2005] ECR II-5839, para. 64.
} 
therefore generally not be considered as a reviewable act, unless it constitutes an act capable to produce effects on the applicant's legal sphere. ${ }^{47}$

Furthermore, the European courts have held that, even where the requested act would be reviewable, it does not necessarily mean that the rejection itself would be reviewable. In particular, in DuPont, the refusal to open an investigation was considered a reviewable act because the applicant had specific procedural guarantees in the decision-making process. ${ }^{48}$ If there are no such procedural guarantees the refusal to initiate a procedure will in principle not constitute a reviewable act.

\subsubsection{Preliminary Question of Validity}

In the system of remedies created by Treaties, EU measures can, in principle, be challenged not only directly through an action for annulment, provided under Article 263 TFEU, but also indirectly through a question of validity, by bringing an action against a national measure and in the national proceedings challenging the validity of the underlying EU measure. Therefore, in cases where the final measure is one adopted by a national authority, initial or intermediate EU measures adopted in the context of composite procedures could be challenged indirectly through the use of Article 267 TFEU.

According to the case law of the CJEU, the range of measures that can be challenged indirectly through a question of validity is wider than those, which are amenable to judicial review in direct actions. For, the CJEU held that in preliminary questions of validity 'all acts of the institutions without exceptions' could be challenged. ${ }^{49}$ This could imply that initial and intermediate (positive and negative) EU measures could be challenged in national proceedings directed at the challenge of the final national measure. This conclusion is supported by the Tillack case, in which the applicant tried to challenge at the European level the transfer of information from OLAF to the competent national authorities. While the Court of First Instance found that the transfer itself could not be considered a reviewable act, in response to the suggestion that this conclusion may deprive the applicant of effective judicial protection, it did state that the applicant had the opportunity to bring an action before the national court and ask it to send a preliminary question to the CJEU..$^{\circ}$

47 See Case C-39/93 P Syndicat Francais de l'Express International (SFEI) v. Commission [1994] ECR I-2681, concerning a Commission's letter of rejection of the applicant's request to pursue a competition infringement.

48 See Case T-113/oo DuPont Teijin Films Luxembourg and Others v. Commission [2002] ECR II03681.

49 Case C-322/88 Grimaldi [1989] ECR 4407, para. 8.

50 Case T-193/04 Tillack v. Commission [2006] ECR II-3995, para. 80. 
Finally, it should be pointed out that failures to act by a EU institution cannot be the subject matter of a question of validity. ${ }^{51}$

\subsubsection{Action for Failure to Act}

Pursuant to Article 265 TFEU, the European courts may review failures to address to the applicant any act, other than a recommendation or an opinion. The interpretation followed by the European courts, in application of the unity principle between action for annulment and action for failure to act, is that reviewable omissions are those failures to adopt an act which produces legal effects for the purposes of an action for annulment. ${ }^{52}$

While the application of this criterion leads to the conclusion that omissions to adopt a final measure can, in principle, be challenged with an action for failure to act, ${ }^{33}$ the same cannot be argued for initial and intermediate failures to issue a measure by the EU institutions. Indeed, the application of the IBM criterion would lead to the conclusion that failures to adopt initial or intermediate measures would generally not be considered as reviewable under Article $26_{5}$ TFEU. However, 'in some cases, the non-adoption of an act can produce legal effects, even though the act itself would not produce such effects'. ${ }^{4}$ This is why, in exceptional cases, the European courts have considered failures to adopt initial or intermediate measures to be reviewable if the omission was in itself capable of affecting the applicant legal sphere. ${ }^{55}$

\subsubsection{Reviewable Acts at the National Level}

What constitutes a reviewable act at the Member States level is in principle determined by national procedural rules, in application of the principle of national procedural autonomy. ${ }^{56}$ Prior research has, however, shown that preparatory measures, hence initial and intermediate measures in composite procedures are generally not considered reviewable, because they are considered incapable of directly affecting the applicant's legal sphere. ${ }^{57}$

\footnotetext{
Case C-68/95 T. Port [1996] ECR I-833, para. 53.

Case C-170/02 P Schusselverlag and others v. Commission [2003] ECR I-9889.

Case C-282/95 P Guerin Automobiles v. Commission [1997] ECR I-1503, para. 38.

4 Herwig C.H. Hofmann, Gerard C. Rowe \& Alexander H. Türk, Administrative Law and Policy of the European Union, 853.

55 See e.g. Case T-28/90 Asia Motor France and others v. Commission [1992] ECR II-2285.

56 Case 33/76 Rewe [1976] ECR 1989; Case 45/76 Comet [1976] ECR 2043.

57 Mariolina Eliantonio, Europeanisation of Administrative Justice? The influence of the CJEU's case law in Italy, Germany and England (Europa Law Publishing 2008), Chapter 1, where this conclusion is reached for the German and Italian legal systems.
} 
However, in Oleificio Borelli, the CJEU held that a national measure that prevented legal action from being taken against a mere administrative preparatory act would be in violation of the right of access to justice..$^{8}$ In this case, an Italian firm sought the annulment of a Commission measure, on the grounds that the underlying measure adopted by the competent national authority was void. The CJEU ruled that, while it had no jurisdiction to rule on the unlawfulness of a measure adopted by a national authority, the negative opinion issued by the national authorities should have been challenged before a national court and that the requirement of effective judicial protection obliges the Member States, 'to regard an action brought for that purpose as admissible even if the domestic rules of procedure do not provide for this in such a case' ${ }^{59}$

This conclusion has been reiterated recently by the CJEU in the case Livimaa Lihaveis MTÜ that, like Oleificio Borelli, also concerns multi-level decisionmaking proceedings. ${ }^{60}$ In this case, Estonian law prevented applicants from challenging before any court the rejection of an application for funding under the European Regional Development Fund. The Court found such a rule to be in breach of Article 47 of the European Charter of Fundamental Rights.

In the CJEU's view, therefore, in cases where the applicant would otherwise be deprived of all forms of judicial review, interlocutory measures must be susceptible to review by the national courts, even though they are mere preparatory steps and despite the fact that the rules governing domestic administrative law do not provide for review of this type of measure.

\subsubsection{Conclusion: Reviewable Acts and Composite Procedures}

On the basis of the analysis carried out above, one can conclude that, because of the multiple steps involved in the decision-making process of the composite procedures, judicial protection issues may arise because of the preparatory nature of the actions and omissions occurring before the final decision is adopted, which do not always qualify as reviewable acts under national or EU law.

In cases in which the final measure of a composite procedure is adopted by a EU authority or a different national authority than the one initiating or participating in the process, there may be situations in which the applicant may

58 Case C-97/91 Oleificio Borelli S.p.A.v. Commission of the European Communities [1992] ECR I6313.

59 Oleificio Borelli S.p.A., para. 13 .

60 Case C-562/12 Livimaa Lihaveis MTÜv. Eesti-Läti programmi 2007-2013 Seirekomitee, judgment of 17 September 2014, ECLI:EU:C:2014:2229. 
question the lawfulness of the underlying national initial or intermediate measure (positive or negative, act or omission). In such situations, despite the principle of national procedural autonomy (which may consider such measure as not amenable to judicial review), the Borelli case examined above demands reviewability of national preparatory measures.

The reverse situation occurs in cases in which it is a national authority that is entrusted to take the final measure of the decision-making process and the applicant wishes to challenge an initial or intermediate EU measure. As shown above, in such cases, a direct challenge against the preparatory measure is only possible in case there is a measure (positive or negative, act or omission) capable of affecting the applicant's legal sphere. In cases of composite procedures this situation is not likely to occur. Therefore, the only avenue left for the applicant is to pursue a national claim against the final measure and, before the national court, plead the illegality of the underlying EU measure. This is, however, not possible in the case of a failure to act on the part of the EU institutions.

\subsection{Standing}

\subsubsection{Standing at the EU Level}

Even assuming that the initial, intermediate or final EU positive or negative action or omission constitutes a reviewable act, the second hurdle to overcome is that of gaining standing before the EU courts in an action for annulment or an action for failure to act. The standing requirements for both actions will be examined below.

\subsubsection{Action for Annulment}

Pursuant to Article 263 TFEU, a private party may be able to gain standing in an action for annulment in three situations: if he is the addressee of the measure; if the measure is of individual and direct concern to him; or if he is challenging a regulatory act which does not entail implementing measures and which is of direct concern to him.

The concept of 'regulatory act' is not defined in the list of instruments contained in Article 288 TFEU. The European courts have defined it to be a nonlegislative measure of general application. ${ }^{61}$ So a measure which is not adopted

61 See Case C-583/11 P Inuit Tapiriit Kanatami and Others v. European Parliament and Council of the European Union [2013] nyr. For a discussion of the case law leading up to this ruling, see Haakon Roer-Eide and Mariolina Eliantonio, The Meaning of Regulatory Act Explained: Are There Any Significant Improvements for the Standing of Non-Privileged Applicants in Annulment Actions?, German Law Journal (2013), available at www.germanlawjournal.com/ index.php?pageID=11\&artID $=1581$. 
following the ordinary or special legislative procedures within the meaning of paragraphs 1 to 3 of Article 289 TFEU, whether adopted by the Commission or not. $^{62}$ Furthermore, in application of recent European case law, an 'implementing measure' can very well be a final measure in a composite procedure. ${ }^{63}$

Considering that, in composite procedures, initial or intermediate measures are steps in the decision-making process, they will hardly ever be addressed to an individual, as they mostly consist of inter-institutional communications. Furthermore, even in cases of a final measure by the EU, the applicant may wish to challenge a measure addressed to a third party. Hence, an applicant who wishes to challenge an EU measure would need to prove, very often, direct concern, and apart from cases of regulatory acts not entailing implementing measures (i.e. final EU measures adopted with a non-legislative procedure), also individual concern.

\section{Direct Concern}

The CJEU has held consistently that a measure is of direct concern only if it affects the applicant's legal position directly and it leaves no discretion to the addressees of the measure who are entrusted with its implementation. In other words, a direct link between the challenged measure and the loss or damage that the applicant has suffered must be established. ${ }^{64}$ Moreover, the implementation must be automatic and result from EU rules without the application of other intermediate rules. If the measure leaves national authorities of the Member States a degree of discretion as to how the measure should be implemented, the applicant will not be considered to be directly concerned. ${ }^{65}$

There are, however, some situations in which the final national measure does not entail any discretion on the part of the competent authorities. If the final national measure merely takes up the information provided by the European authorities, the CJEU has considered that there will be direct concern. $^{66}$

62 Case T-93/10 Bilbaina de Alquitranes, SA, and others v. Commission [2013] nyr, para. 55-59.

63 Case C-274/12 P Telefónica SA v. European Commission [2013] nyr.

64 Cases C-41-44/70 NV International Fruit Company and others v. Commission of the European Communities [1971] ECR 411; Case C-207/86 Asociación Profesional de Empresarios de Pesca Comunitarios (Apesco) v. Commission of the European Communities [1988] ECR 2151, para. 12. Recently, C-417/04 P Regione Siciliana v. Commission of the European Communities [2006] ECR $\mathrm{I}-03881$.

65 See, for example, Case C-69/69 SA Alcan Aluminium Raeren and others v. Commission of the European Communities [1970] ECR 385; Case C-222/83 Municipality of Differdange and Others v. Commission of the European Communities [1984] ECR 2889.

66 Cases C-41-44/70 NV International Fruit Company and others v. Commission of the European Communities [1971] ECR 411, para. 25. In this case, the duty of national authorities was to collect information, which was submitted to the Commission. The latter took a decision, which then the national authorities had to carry out without any discretion. The same conclusion was 
The European courts have dealt with such situations in a specific type of composite procedure, which is the granting of funds to Member States. This group of cases concerns claims brought by thirds parties when the EU adopts decisions on the provisions of funds to Member States to finance certain projects. The question is therefore whether an individual, who is the recipient of the fund, but is not the addressee of the EU decision, can challenge the latter before the EU courts. The case law concerning the allocation of European funds shows clearly that, where the Member State has discretion in the follow-up of the decision-making process, the European courts will not recognise direct concern. ${ }^{67}$

Under certain exceptional circumstances, the CJEU has considered the applicants to be directly concerned even where the challenged measure leaves those entrusted with its implementation with a degree of discretion. In particular, the CJEU has held that direct concern exists - even when there is discretion - in cases where: at the time when the measure was adopted, there was no real doubt as to how the discretion would be exercised; ${ }^{68}$ or where it is in theory possible for the addressees of the measure not to give effect to the EU measure and their intention to act in conformity with it is not in question. ${ }^{69}$ This definition of direct concern has been considered equally applicable to the cases of challenges against regulatory acts. ${ }^{70}$

The application of this case law entails that, apart from the cases in which national authorities have no discretion in the implementation of EU law, generally an initial or intermediate EU measure in a composite procedure will not

reached in Case C-354/87 Weddel a Co. BVv. Commission of the European Communities [1990] ECR I-03847, para. 19 .

67 See Case C-291/89 Interhotel, Sociedade Internacional de Hoteis SARL v. Commission of the European Communities [1991] ECR I-02257. In this case, Portugal did not have any discretion in the management of the fund so the Court found that the applicant has direct concern to challenge the EU measure granting the fund. In contrast, where the relationship is really between the Member States and the EU institutions in the challenged EU measure, there will not be direct concern. Member States have discretion on what to do with the funds, they can also decide not to claim money back and bear financial burden themselves so the European courts have considered that, in such cases, the European decisions do not directly affect the legal sphere of the third parties. See e.g. Joined Cases 89 and 91/86 L'Étoile commerciale and Comptoir national technique agricole (CNTA) v. Commission of the European Communities [1987] ECR 3005; Case T-244/o0 Coillte Teoranta v. Commission of the European Communities [2001] ECR II-01275 para. 44 .

68 Case 11/82 Piraiki-Patraiki v. Commission of the European Communities [1985] 207; Cases C-445/07 P and C-455/07 P Commission of the European Communities v. Ente per le Ville Vesuviane and Ente per le Ville Vesuviane v. Commission of the European Communities [2009] ECR I-07993.

69 Case C-417/04 P Regione Siciliana v. Commission of the European Communities [2006] ECR $\mathrm{I}-03881$.

70 Case T-94/10 Rütgers Germany GmbH and Others v. European Chemicals Agency (ECHA) [2013] nyr, para. 38 and 59 . 
be considered as having direct concern for the applicant because there is a further national or EU measure to be challenged. This position the European courts hold, has found clear application in a group of cases concerning a specific composite procedure, namely that arising out of the Habitats Directive. In such cases, the European courts have consistently denied standing to applicants who tried to challenge an intermediate Commission via an action for annulment, under Article $26_{3}$ TFEU, on the grounds that it did not affect directly the applicant's legal sphere. ${ }^{71}$

The case law on direct concern implies also that, in principle, for final EU measures (whether they have the nature of regulatory acts or not), the requirements of direct concern would be met because a final measure is capable of directly affecting an individual's legal sphere. However, in composite procedures, it can often happen that the final EU measure merely confirms a decision taken by the national authorities. In such cases, direct concern will be found only when the European measure 'renders valid' the national measure. ${ }^{72}$ For example, in the case $D S T V,{ }^{73}$ the final EU measure contained a denial, addressed to the UK, to retain a national measure, and direct concern was denied. Final confirmatory EU measures are of direct concern only if they have retroactive effects; otherwise according, to the EU courts, the challenge should be directed against the national measure.

Furthermore, direct concern cannot be proven in cases of challenges brought by associations, since it will be hardly ever possible for this category of applicants to prove that there is a direct link between the measure at stake and a certain loss or damage they suffered, as is required by the case law of the European courts. The consequence of this is that even final EU measures which result from composite procedures may, sometimes, be immune from judicial review because those who would be able to prove direct concern have no interest in bringing judicial proceedings, while associations protecting collective or diffuse interests may not be able to gain standing.

${ }^{71}$ Case T-136/04 Rasso Freiherr von Cramer-Klett and Rechtlerverband Pfronten v. Commission of the European Communities [2006] ECR II-01805; Case T-137/04 Kurt Martin Mayer and Others v. Commission of the European Communities [2006] ECR II-01825; Case T-122/o5 Robert Benkö and Others v. Commission of the European Communities [2006] II-02939; Case T-150/05 Markku Sahlstedt and Others v. Commission of the European Communities [2006] ECR II-01851, confirmed in appeal in Case C-362/o6 P Markku Sahlstedt and Others v. Commission of the European Communities [2009] ECR I-02903.

72 Joined Cases 106 and 107-63 Alfred Toepfer and Getreide-Import Gesellschaft v. Commission of the EEC [1965] ECR 00405.

73 Case T-69/99 Danish Satellite TV (DSTV) A/S v. Commission of the European Communities [2000] ECR II-04039. 


\section{Individual Concern}

The new standing requirements introduced by the Lisbon Treaty have introduced the possibility for private parties to prove only direct concern in cases of challenges against regulatory acts not entailing implementing measures, thereby dispensing with the need to prove individual concern. Therefore, for some of the final EU measures, which are concluding a composite procedure, an applicant would not need to prove individual concern. This would be the case if the composite procedure were concluded, for example, with a Commission delegated or implementing regulation or an act of the European Chemicals Agency.

However, if the composite procedure was concluded with a Commission regulation adopted with the ordinary or special legislative procedure, the requirements of 'regulatory act' would not be fulfilled and individual concern would have to proven. Similarly, individual concern always needs to be proven in challenges against initial or intermediate EU measures, regardless of the legislative procedure which was used, because such acts would 'entail implementing measures' and thus not be able to benefit from the looser standing requirements introduced by the Lisbon Treaty.

The definition of individual concern was first given in the Plaumann case and is still the reference for determining 'individual concern'. ${ }^{74}$ In this case, the CJEU established that private parties are able to seek judicial review of decisions not expressly addressed to them only if they can distinguish themselves from all other persons, not only actually but also potentially. In other words, the applicants must show that the decision 'affects them by reason of certain attributes which are peculiar to them or by reason of circumstances in which they are differentiated from all other persons and by virtue of these factors distinguishes them individually just as in the case of the person addressed'. ${ }^{75}$ As a result, individual concern cannot be established when the applicant operates a trade which could be engaged in by any other person at any time. In particular, the applicant has to show, according to the case law developed by the CJEU, that at the time when the decision was adopted they belonged to a so-called 'closed class', affected differently by the EU measure than all other persons. ${ }^{76}$

Case C-25/62 Plaumann \& Co. v. Commission of the European Economic Community [1963] ECR 95 .

75 Ibid., 107.

76 E.g. joined Cases C-106 and 107/63 Alfred Toepfer and Getreide-Import Gesellschaft v. Commission of the European Economic Community [1965] 405. 
The Plaumann test constitutes a very restrictive approach to individual standing, which has sparked a vast amount of academic debate and criticism, ${ }^{77}$ and has been challenged even from within the EU courts. ${ }^{78}$

Concerning specifically claims brought by associations, these actions have only been considered admissible in three cases: ${ }^{79}$ (a) when a legal provision grants procedural rights to these associations; ${ }^{\circ \circ}$ (b) where every single member of the association would be directly and individually concerned ${ }^{81}$ and (c) where the association's interests, and especially its position as a negotiator, is affected by the measure. ${ }^{82}$

These requirements have made it almost impossible for associations to ever succeed in showing individual concern given that the cases under (a) are rare

77 For criticism on the standing requirements of individual applicants, see, ex multis, Angela Ward, 'Locus Standi under Article 230(4) of the EC Treaty: Crafting a Coherent Test for a Wobbly Polity' (2003) Yearbook of European Law, 45; Anthony Arnull, 'Private Applicants and the Action for Annulment since Codorniu' (2001) Common Market Law Review, 7 ; Jose Manuel Martin Cortés, 'Ubi ius, Ibi Remedium? Locus Standi of Private Applicants under Article 230(4) EC at a European Constitutional Crossroads' (2004) Maastricht Journal of European and Comparative Law, 233; A Abaquense de Parfouru, 'Locus Standi of Private Applicants under the Article 230 EC Action for Annulment: Any Lessons to be Learnt from France?’ (2007) Maastricht Journal of European and Comparative Law, 361; Adam Cygan, 'Protecting the Interests of Civil Society in Community Decision-making: The Limits of Article 230 EC' (2003) International and Comparative Law Quarterly, 995; Xavier Lewis, 'Standing of Private Claimants to Annul Generally Applicable European Community Measures: If the System is Broken, where Should it be Fixed?' (2006-2007) Fordham International Law Journal, 1496; Albertina Albors-Llorens, 'Sealing The Fate of Private Parties in Annulment Proceedings? The General Court and the New Standing Test In Article 263(4) TFEU', Cambridge Law Journal, 52.

78 Opinion of Advocate General Jacobs in Case C-50/00 P Unión de Pequeños Agricultores v. Council of the European Union [2002] ECR I-6677; Case T-177/o1 Jégo-Quéré a Cie SA v. Commission of the European Communities [2002] ECR II-2365.

79 Case C-321/95 P Stichting Greenpeace Council (Greenpeace International) and Others v. Commission of the European Communities [1998] ECR I-1651; T-122/96 Federazione nazionale del commercio oleario (Federolio) v. Commission of the European Communities [1997] ECR II-1559.

80 Case C-191/82 EEC Seed Crushers' and Oil Processors' Federation (FEDIOL) v. Commission of the European Communities [1983] ECR 2913; T-12/93 Comité Central d'Entreprise de la Société Anonyme Vittel and Comité d'Etablissement de Pierval and Fédération Générale Agroalimentaire v. Commission of the European Communities [1995] ECR II-1247.

81 Joined Cases T-447/93, T-448/93 and T-449/93 Associazione Italiana Tecnico Economica del Cemento and British Cement Association and Blue Circle Industries plc and Castle Cement Ltd and The Rugby Goup plc and Titan Cement Company SA v. Commission of the European Communities [1995] ECR II-1971; Case T-380/94 Association internationale des utilisateurs de fils de filaments artificiels et synthétiques et de soie naturelle (AIUFFASS) and Apparel, Knitting Q Textiles Alliance (AKT) v. Commission of the European Communities [1996] ECR II-2169; T-229/02 Osman Ocalan acting on behalf of Kurdistan Workers' Party (PKK) v. Council of the European Union [2008] ECR II-45.

82 Joined Cases 67/85 R, 68/85 R and 70/85 R Kwekerij Gebroeders van der Kooy BV and others v. Commission of the European Communities [1985] ECR 1315; Case T-84/01 Association contre l'horaire d'été (ACHE) v. Council of the European Union and European Parliament [2002] II-99. 
and the cases under (b) are as difficult (if not harder) to be successful as cases concerning individuals, given the strict interpretation of the Plaumann formula. Successful cases under (c) are also not very common since the CJEU has held that the test to be met is that, the position of the association as negotiator is clearly defined and must be related to the subject matter of the contested act, and that that position must have been affected by the adoption of the contested act. $^{83}$ The fact that an association has communicated information to an EU institution or has tried to influence the position adopted by the national authorities in the EU legislative procedure has been regarded as not sufficient in itself to show that the act adopted affects an association in its position as a negotiator. ${ }^{84}$

Furthermore, the application of the Plaumann doctrine to claims by associations purporting to protect the diffuse interests has meant that claims by, for example, environmental associations have consistently been rejected. ${ }^{85}$ The same can be argued with regard to collective interests, such as patient organisations with regard to medicine authorisations. ${ }^{86}$

\subsubsection{Action for Failure to Act}

The last paragraph of Article 265 TFEU grants standing to those individual and legal persons who can claim that the EU institutions, bodies, agencies or offices have failed to address an act, other than a recommendation or opinion, to them.

However, in spite of the more stringent wording of Article 265(3) TFEU in comparison with Article 263(4), the CJEU has held that the two provisions prescribe one and the same method of recourse. Consequently, according to the CJEU, the scope of the action for failure to act is not confined to the defen-

83 Case C-106/98 P Comité d'entreprise de la Société française de production, Syndicat national de radiodiffusion et de télévision CGT (SNRT-CGT), Syndicat unifié de radio et de télévision CFDT (SURT-CFDT), Syndicat national Force ouvrière de radiodiffusion et de télévision and Syndicat national de l'encadrement audiovisuel CFE-CGC (SNEA-CFE-CGC) v. Commission of the European Communities [2000] ECR I-3659, para. 45.

84 Case T-391/o2 Bundesverband der Nahrungsmittel- und Speiseresteverwertung eV and Josef Kloh v. European Parliament and Council of the European Union [2004] II-1447; T-264/03 Jürgen Schmoldt and Others v. Commission of the European Communities [2004] II-1515.

85 Case T-236/04 and T-241/04, European Environmental Bureau (EEB) and Stichting Natuur en Milieu v. Commission [2005] ECR II-04945; Case T-91/07 WWF-UK Ltd. v. Council [2008] ECR II-81, confirmed in appeal in Case C-355/08 P WWF-UKv. Council [2009] ECR I-73; Case T-37/04 Regiao autónoma dos Acores v. Council [2008] ECR II-103, confirmed in appeal in Case C-444/o8 Regiao autónoma dos Acores v. Council [2009] ECR I-200. For a closer examination of this case law, see M. Eliantonio, 'Towards an ever dirtier Europe?: the restrictive standing of environmental NGOs before the European Courts and the Aarhus Convention, Croatian Yearbook of European Law (2011), 69.

86 A. Keessen, European Administrative Decisions - How the EU Regulates Products on the Internal Market, 174 . 
dant institution's failure to adopt a particular measure addressed to the applicant: this means that it is, in principle, possible to challenge a failure to adopt a measure of general application, but the requirements of individual and direct concern will have to be met. ${ }^{87}$

Hence, mutatis mutandis, all considerations made above concerning the standing for individuals in actions for annulment may be applied with regard to actions for failure to act.

\subsubsection{Standing at the National Level}

As far as national measures are concerned, prior research has revealed a wide variety of systems of standing at the national level. However, what has also been made clear is that, in the vast majority of the Member States, the minimum threshold required to achieve standing is that of interest. The interest has to be qualified as direct, personal and certain, with special rules applying to organisations defending collective or diffuse interests. ${ }^{88}$ Without being able, in the context of this paper, to carry out a closer examination of the standing rules at the national level, it can be safely argued that, in general, the requirement of a direct interest is hard to meet when the measure at stake is of a mere preparatory nature.

Nevertheless, it could be argued, in application of the Borelli case law discussed in Section 3.2.2, that this case law demands not only reviewability of national preparatory measures, but also the disapplication of national standing rules that would preclude the admissibility of the claim. Indeed, looking at the case law from a teleological point of view, it would hardly solve the judicial protection gap to admit that a preparatory measure is reviewable in principle, but to reject the claim on grounds of lack of direct interest. Hence, it can be concluded that national initial or intermediate measures should be subject to judicial review in national courts because of the requirements set by the European courts.

In case of final national measures, some strict standing conditions may be seen as a bar to judicial review for third parties and associations, which may

87 Case C-68/95 T.Port GmbH Q Co. KG v.Bundesanstalt für Landwirtschaft und Ernährung [1996] ECR I-6065, para. 59; Case T-17/96 Télévision française 1 SA (TF1) v.Commission of the European Communities [1999] ECR II-1757, para. 27; Case T-103/99 Associazione delle cantine sociali venete v. European Ombudsman and European Parliament [2000] ECR II-4165.

88 Mariolina Eliantonio, Chris Backes, C.H. van Rhee, Taru Spronken \& Anna Berlee, Standing up for Your Right(s) in Europe - A Comparative Study on Legal Standing (Locus Standi) before the EU and Member States' Courts, Intersentia 2013. See in particular the chapter on standing before national administrative courts. 
imply that a measure may effectively be immune from judicial review. In systems in which one needs to prove the infringement of a right to gain standing before a national court, it is debatable, for example, whether consumers associations, competitors or other third parties may be able to challenge a national measure in the field of product regulation. ${ }^{89}$

\subsubsection{Conclusion: Standing and the Gaps of Judicial Protection}

The analysis carried out above has shown that, even where the hurdle of a reviewable act has been overcome, individuals may be denied standing by the European or national courts because of a lack of standing.

At the EU level, individuals may have a hard time gaining standing in cases concerning EU initial or intermediate measures (whether acts or omissions) because these measures are hardly ever addressed to individuals, hence the need to prove, firstly, direct concern. This requirement, however, is difficult to meet in such situations, because of the necessity to show a change in the applicant's legal sphere, which is generally considered to occur only when a final decision has been issued. Furthermore, even where direct concern could be proven (because, for example, the final national measure does not entail any discretion on the part of the national authorities), the challenge would still necessarily be directed against a measure entailing implementing measures so individuals may be denied standing because of the lack of individual concern, due to application of the traditional Plaumann doctrine. In such cases, as with cases in which the EU measure is considered not reviewable, individuals are obliged to bring an action against the final national measure and challenge the validity of the underlying EU measure with a question of validity.

Furthermore, as far as final EU measures are concerned, individuals may gain standing, when the challenge is directed against a regulatory act not entailing implementing measures, but associations will hardly ever be able to prove direct concern. Furthermore, individual concern may be denied in cases of challenges brought by individuals or associations even against final EU measures which do not qualify as regulatory acts, effectively rendering certain EU acts immune from judicial review altogether.

Similarly, at the national level, challenges against initial or intermediate measures may in principle not be admissible. However, the application of the Borelli case law to such situations would seem to imply that standing in such

89 A. Keessen, European Administrative Decisions - How the EU Regulates Products on the Internal Market, $190 \mathrm{ff}$. 
cases must be granted in order for Member States to comply with the principle of effective judicial protection. Furthermore, even final national measures may sometimes not be challenged, for example, by associations in legal systems adhering to strict standing requirements.

\section{$4 \quad$ Case Study}

The considerations made above will be applied in a specific case study constituting one of the most complex models of composite procedure, i.e. the one arising from the application of Regulation 258/97 concerning novel foods and novel food ingredients. ${ }^{\circ}$ As mentioned in Section 2.2.4, this composite procedure entails an administrative decision-making procedure commencing in one Member State, which is followed by input from the EU level or another Member State. In the end, the Commission takes the final decision. ${ }^{{ }^{1}}$ In the following, the steps of the decision-making process will be analysed and the potential gaps of judicial protection will be examined..$^{2}$

\subsection{The Initial Safety Assessment}

The applicant may wish to complain against the content of the safety assessment, since the conclusion reached by the national authority may entail that the simplified procedure does not apply, and the European Commission needs to perform a further assessment. An applicant who claims for example, that the national authorities have misinterpreted the relevant facts or applicable legal provisions, may have a significant interest in bringing legal proceedings, because the further assessments will entail a lengthier and more costly decision-making process, as well as a longer waiting time before the applicant can market their products.

In application of the strict separation of jurisdiction, this measure could only be challenged before the competent national court of the Member State in which the assessment was carried out. In the majority of Member States,

90 Regulation 258/97 concerning novel foods and novel food ingredients [1997] OJ L 43/1.

91 On this instrument and for further literature concerning it, see T. Ehnert, 'The Legitimacy of New Risk Governance - A Critical View in Light of the EU's Approach to Nanotechnologies in Food' (2014) European Law Journal, DOI: 10.1111/eulj.12082.

92 A similar exercise, with specific reference to product regulation, although not specifically covering composite procedures, and concentrating mostly on the final measure of the analysed decision-making processes, can be found in A. Keessen, European Administrative Decisions How the EU Regulates Products on the Internal Market. Further on this see also G. Sydow, Verwaltungskooperation in der Europäischen Union, Zur horizontalen und vertikalen Zusammenarbeit der europäischen Verwaltungen am Beispiel der Productzulassungsrecht, Tübingen 2004. 
because of the mere preparatory nature of the measure, the initial safety assessment would in principle not be considered a reviewable measure. However, by applying the Borelli case law, the national courts would have to admit a claim against this type of measure. If the measure were to be declared unlawful, the ruling would have, as such, no effects on the further steps taken at the European level.

\subsection{The Objection by the Member States}

The applicant may want to complain against a possible objection submitted by another Member State, due to the submission of an objection entailing that a longer and more complex procedure will have to be followed, like in the case above. Also for this measure, the hurdle is the fact that it is a preparatory measure, and the same limitation discussed above on the scope of review applies. While the application of the Borelli case law would imply the admissibility of such an action, in this case the applicant also faces the additional hurdle of having to litigate in a different legal system than the one in which he submitted his initial application, including all difficulties attached to accessing an unknown judicial system.

Third parties (e.g. a competitor of the applicant or a consumer organisation) may also want to complain about the non-submission of an objection by a Member State, since in such cases the simplified procedure will apply, entailing fewer controls on a potentially dangerous substance. It is debatable whether omissions fall within the scope of application of the Borelli case law. On the one hand, as with the reasoning presented with regards to standing, it would be difficult to sustain from a logical point of view that only actions and not omissions are reviewable if the aim is to ensure effective judicial protection of individuals. Yet, on the other hand, it could be argued that reviewable omissions are only those occurring in a situation in which a national authority had a duty to act (or at least to reply to an individual's application), that does not seem to be the case according to the applicable legislation.

\subsection{The Objection by the Commission}

As with the objections of Member States, the applicant may have the same interest in challenging an objection submitted by the Commission, since it entails a longer and more complex procedure. However, applying the $I B M$ case law discussed above, the objection submitted by the Commission would not be considered a reviewable act, hence a potential action for annulment would be deemed inadmissible because the challenged measure would be deemed not reviewable because of its preparatory character. Similarly, also a non-submission of an objection would not be deemed reviewable because, as discussed under Section 5.2.1.3, actions for failure to act can be directed only 
against omissions to issue measures which would themselves have constituted reviewable measures.

However, the case law of the CJEU 93 suggest that this measure would, in principle, be challengeable together with the final measure of the decisionmaking process issued by the Commission.

\subsection{The Final Authorization}

If the European Commission would not grant an authorisation to market a product or would impose certain limitations on marketing or labeling, clearly the decision would constitute a reviewable act, because it is an act capable of affecting the individuals' legal sphere. Furthermore, the authorisation is taken in the form of a Commission Implementing Decision; hence under the new rules of standing, introduced by the Lisbon Treaty, this would constitute a regulatory measure (i.e. a non-legislative measure of general application), which by its very nature does not entail implementing measures.

Therefore, the applicant would be dispensed with the need to prove individual concern and would certainly be able to prove direct concern, because the measure would have a direct impact on the applicant's legal sphere, hence the action would be admissible.

However, once declared admissible, the substance of the action will be limited to the part of the decision-making process that took place before the Commission. In other words, the European court will only review the risk assessment carried out at the EU level and the formal requirements of the relevant decision-making process (together with, possibly the objection raised by the Commission). But will not review, for example, the Member State's decision to send the file to the Commission in the first place and the preliminary risk assessment made by the national authorities.

Furthermore, it is quite doubtful whether third parties, e.g. a consumer NGO, would be able to challenge an authorisation measure. They would most likely not be able to prove direct concern, so an authorisation to market a product (with potentially dangerous consequences for the human health) would in effect not be able to be challenged by those wishing to do so. While those who could challenge the measure, e.g. the applicant, may not necessarily have an interest in doing so (because the decision is favourable to him).

93 See above under footnote 59 . 


\subsection{Conclusion}

The examination provided in the preceding paragraphs has shown that the preparatory national measures (objections and preliminary assessment) could form the subject matter of an action before the relevant judicial instances, despite their preliminary character, if national courts are willing to correctly apply the Borelli case law. Once such an action has been concluded with a determination of unlawfulness of the preparatory measure at stake, the applicant would need to subsequently bring an action for annulment, under Article $26_{3}$ TFEU, against the authorisation decision.

The objection submitted by the Commission would, on the other hand, not be considered reviewable, but could be subsequently reviewed in a claim against the final decision. While the applicant would be able to bring a challenge against the final measure (because of the more relaxed standing criteria introduced by the Lisbon Treaty), other interested parties (such as a consumer association), however, would be denied standing to challenge the final Commission determination because of a lack of standing according to the CJEU's criteria.

\section{Judicial Review and Composite Procedures: Potential Gaps, Existing Solutions, and Possible Alternatives}

The analysis carried out above has shown that, while composite procedures have become increasingly important in the system 'integrated administration' of the EU, ${ }^{94}$ the system of judicial review has remained anchored to a traditional view of executive federalism. This implies a strict separation between national and European courts, which remain each exclusively competent for the acts and omissions imputable to the authorities falling under their jurisdiction.

This system is no longer capable to react adequately to those decision-making processes, which entail the contribution of national and EU authorities, participating with various intensities and with measures of a more or less formalized nature. As the drafters of the ReNEUAL Model Rules have put it, the concrete

94 Turk and Hofmann argue that 'integrated administration is at the core of the EU's legal and political system. Integrated administration is what renders the EU system of government and governance unique and distinct from models we know from the Member States' legal systems - be they more unitary or more federal in their internal structures. It is the substance behind the theoretical notion of shared sovereignty'. Herwig C.H. Hofmann \& Alexander Türk, 'The Development of Integrated Administration in the EU and its Consequences'(2007) European Law Journal, 271. 
danger exists the individuals "may fall in "black hole" between situations covered by EU-level review and accountability mechanisms and those of Member States'. ${ }^{95}$ If the EU is to uphold its qualification of a 'Community based on the rule of law', ${ }^{96}$ therefore, it has to face the challenge to adapt judicial supervision to the emerging reality of an 'integrated administration'.

As presented above, the CJEU has tried to provide solutions to the lack of judicial protection occurring in the case of composite procedures. First of all, when a challenge is made directly against a national initial or intermediate measure, the Borelli case law demands reviewability of such measures before the national courts even where, according to the applicable national procedural rules, they may not have otherwise been reviewable. While this requirement imposed by the European courts seems to fill the possible gaps of judicial protection, it does leave some questions open. First of all, there is no assurance that national courts, through the disapplication of the national procedural rules to the contrary, will admit claims against national preparatory measures. Individuals may forget to rely on this case law before the national courts and the courts themselves may be unaware of or unwilling to apply the European requirements. Furthermore, reliance on national courts' willingness to set their own procedural rules aside may bring about a certain lack of legal certainty, as well as the risk of unacceptable differential treatment if national courts would come to different conclusions in cases of the same or similar preparatory measures taken in the context of composite procedures.

Furthermore, even admitting that the national courts would allow a claim against an initial or intermediate measure (either through the application of their own procedural rules or of the Borelli case law'), the ruling does not have, as such, any influence on the final measure, which may have been based on an unlawful preparatory measure. In such cases, national courts do not have the power to invalidate EU measures or measures issued in a different Member State, on the basis of the Foto-Frost ruling97 and the territoriality principle governing jurisdiction. The applicant would, therefore, need to bring a subsequent claim before the competent national or EU court in order to challenge the lawfulness of the final measure. Needless to say, this involves extra time and costs. Importantly, applicants may well find themselves time-barred because of the two-month time limit provided in Article $26_{3}$ TFEU, unless they would be expected to bring two parallel proceedings before the national and European courts. Furthermore, because of the strict standing requirements applied by

95 Introduction to the ReNEUAL Model Rules; Book I - General Provisions; para. 27.

96 Case 294/83 Les Verts v. Parliament [1986] ECR 1339, para. 23.

97 Case 314/85 Foto-Frost v. Hauptzollamt Lübeck-Ost [1987] ECR 04199. 
the European courts, final EU measures may not be challengeable because of a lack of standing. This problem may be quite significant especially in claims brought by associations for the protection of collective or diffuse interests, since it may render certain EU measures immune from judicial review.

A solution to the extra costs and time (and possibly procedural limitations) involved in the necessity to bring a second challenge against the final EU or national measure would be the creation of a transfer from the national court to the competent EU court. This would at least reduce the time and costs involved for the applicant in preparing an entirely new plea and render the claim admissible despite the expiry of the time limit. A better alternative, from the perspective of the applicant (involving less time and costs), would be the possibility to bring only one claim, against the final measure before the court of the legal system which took the final measure and introduce the possibility of a 'cross' (i.e. to another Member State) or 'reverse' (i.e. by the CJEU to the national level) preliminary ruling system, whereby the competent court could ask a question of validity to a competent court of the legal system where the preliminary measures were issued.

In the reverse scenario of a possible challenge against a preparatory EU measure, the analysis carried out above has shown that, while direct challenges would be hardly admissible, the indirect avenue of the preliminary question of validity could be pursued. As according to the CJEU's view in the Tillack case, triggering the preliminary question of validity should ensure the completeness of the system of judicial protection. In such situations, the problems are admittedly less acute than the scenario discussed above (because there is only one single judicial procedure which the applicant needs to pursue, albeit involving multiple jurisdictions), but the system is in any case not free from shortcomings, many of which have been highlighted eminently by AG Jacobs in his opinion on the UPA case..$^{8}$ In particular, he recalled that access to the CJEU via the preliminary reference procedure is not available to applicants as a matter of right, since national courts (with the exclusion of courts of last instance) may refuse to refer a question of validity of an EU measure to the CJEU or might err in their assessment of the validity of the measure and decline to refer a question to the CJEU on that basis. ${ }^{99}$ In addition, even where a reference is made, it is the national courts that formulate the preliminary questions with the consequence that applicants' claims might be redefined or that the questions referred might limit the range of measures whose validity is being challenged

98 Opinion of Advocate General Jacobs in Case C-50/00 P Unión de Pequeños Agricultores v. Council of the European Union [2002] ECR I-6677. 
before the national court. ${ }^{100}$ Finally, the AG considered that proceedings brought before a national court are more disadvantageous for individuals compared to an action for annulment, under Article 263 TFEU, since they involve delays and extra costs. ${ }^{101}$

An alternative solution could be to expand the scope of reviewable acts under Art. 263 TFEU to preparatory measures which currently, in application of the $I B M$ case law, would not be considered a reviewable act. Consequently the applicant would be able to bring an action for annulment against the preparatory EU measure and another challenge against the final national measure before the competent national judicial instance. ${ }^{102}$ Whether this solution is more favourable to the applicant than the 'single avenue' procedure (with an action before a national court in combination with the preliminary ruling of validity) is questionable, as it may be even more costly and time consuming than the latter option. Furthermore, in such a scenario, the potential applicant may be harmed by the TWD Deggendorf case law, ${ }^{103}$ because if a direct action against a preparatory measure would be open, the applicant, in line with this case law, would be obliged to bring an action against this measure and would be barred from asking a preliminary reference in an indirect action if he had had standing in a direct action.

Another general problem which may occur in any of these constellations is that an individual may not know that the measure he or she is challenging is the product of the elaboration of information which may have been collected and submitted by a different actor, perhaps acting at a different level. Even if he is aware that the decision is the by-product of a multi-level decision-making process, he may not be able to discern which part of the decision are imputable to one or the other participating authority. This may be especially relevant in those composite procedures in which the contribution of the participating authorities consists of the mere provision of information and not in a more formalised measure. In all such cases, all the proposals made above do not provide an effective solution.

Nor can the ReNEUAL Model Rules be resorted to in order to find general solutions to fill the existing gaps of judicial protection given that judicial procedural rules are explicitly excluded from the scope of application of the Model

\footnotetext{
100 Ibid.

101 Ibid., para. 44.

102 This is also proposed by Morgane Tidghi \& Herwig C.H. Hofmann, 'Rights and Remedies in Implementation of EU Policies by Multi-Jurisdictional Networks' (2014) European Public Law, 155 .

103 Case C-188/92 TWD Textilwerke Deggendorf [1994] ECR I-833.
} 
Rules. ${ }^{104}$ The only partial solution offered by the Model Rules is that contained in Book VI concerning specifically information management activities: pursuant to Article VI-40, any person suffering damage from an unlawful processing operation carried out in the context of an information management activity is entitled to receive compensation. ${ }^{105}$ While this provision would certainly enhance the judicial protection of individuals because it would at least provide a compensatory remedy against the unlawful action of the public authorities, it cannot be used to seek the annulment of the management activity as such, which remains governed by national law.

\section{Conclusions and Recommendations}

'Existing approaches to judicial review of administrative activity [...] exhibit shortcomings when faced with an increasingly integrated administration ${ }^{, 106}$

The system of judicial review, as it currently works, seems not to be fully adequate to operate in a system of 'integrated administration', in which not only various jurisdictions may be involved in the decision-making process, but also where there are various forms of dialogue and cooperation amongst them, which may result in more or less formalised types of administrative action. Therefore, while the solutions provided above may seem to (at least partially) fill the gaps of judicial protection currently existing, a thorough re-think of the system of judicial review may, in the long term, be necessary, in order to adapt the system of control of the administrative action to the new system of administrative decision-making.

From the perspective of the measures adopted, the system of composite procedures requires a re-think of the notion of a reviewable act both at national and European levels. Administrative cooperation often takes place in the form of exchange of information, which is generally not considered as a reviewable act and, as such, considered incapable of producing legal effects. However, because of the composite nature of the decision-making the information provided by an authority can have far-reaching consequences, as another authority may base a binding measure on it. Furthermore, preparatory measures, even if adopted in a more formalised way, are generally considered not reviewable both

104 See Part C of Book I, para. 5.

105 See further the explanations contained in Chapter 5 of Part C of Book VI.

106 Herwig C.H. Hofmann \& Alexander H. Türk, 'Legal Challenges in EU Administrative Law by the Move to an Integrated Administration’, in: Herwig C.H. Hofmann \& Alexander H. Türk (Eds), Legal Challenges in EU Administrative Law, 373. 
at the national and European law, with the Borelli and Tillack solutions only providing half-solutions to fill the judicial protection gap. From this point of view, an expansion of the notion of reviewable acts both at the European and national level would be necessary.

More in general, the system of 'integrated administration' requires the necessity to depart from the strict dualistic approach to judicial review. As has been observed, the current mechanism of preliminary ruling only works vertically (i.e. from national courts to EU and not between national courts) and only one way (never from the EU courts to national courts). ${ }^{107}$ As this paper has shown, the traditional two-level structure clashes with the reality of decisionmaking, which is more and more organised in a network structure, and the existence of the preliminary ruling in its current form does not fully serve to fill the existing gaps. Hence the necessity to use the same network structure for the judicial supervision of the administrative action. A possibility to adapt judicial review to the system of 'integrated administration' would be, the setting up of a system whereby 'judicial review could be undertaken by one court with supervision of all participants in the administrative network', ${ }^{108}$ possibly by the court competent according to the procedural rules of the legal system to which the authority which took the final decision belongs. One would, however, also need to foresee rules concerning the enforcement of such a ruling, as the latter would have extra-jurisdictional reach. Also, rules on the inclusion and exclusion of the 'participants' to the judicial proceedings would have to be devised. More importantly, however, such a scenario would imply a recognition of the intertwined nature of the systems of judicial review, before national and European courts, and a final farewell to, on the one hand national sovereignty of the organisation of the judiciary, and on the other hand to the current monopoly of the European courts on the interpretation and application of EU law.

Finally, it would also be necessary for the European courts to re-think their approach to standing. As the case study on the authorisation procedure for novel food has shown, even with the more relaxed standing criteria, introduced by the Lisbon Treaty, associational claims may not be admissible in some circumstances hence immunising certain measures de facto from judicial review. Despite the CJEU's assertions to the contrary, ${ }^{109}$ the requirements of standing

107 Also observed by Herwig C.H. Hofmann, 'Decisionmaking in EU Administrative Law - The Problem of Composite Procedures' (2009) Administrative Law Review, 213-214.

108 Ibid., 214.

109 Case C-50/00 P Unión de Pequeños Agricultores v. Council of the European Union [2002] ECR I-o6677, para. 45: 'While it is, admittedly, possible to envisage a system of judicial review of the legality of Community measures of general application different from that established by the founding Treaty and never amended as to its principles, it is for the Member States, if necessary, in accordance with Article $48 \mathrm{EU}$, to reform the system currently in force.' 
in their current interpretation are a creation of the Court, and it is for the Court to choose whether to broaden the door to private parties' challenges of EU measures.

At a time in which the debate on the possible codification of administrative decision-making procedures has just been ignited by the publication of the ReNEUAL Model Rules, it would be worth opening a parallel debate on whether common rules on decision-making should not be coupled with rules on judicial protection. 